\title{
アクセス性からみた琵琶湖湖岸緑地と隣接集落との つながりについての研究
}

\author{
A Study on Accessibility to the Biwa Lakeshore Park for the Neighbors
}

\author{
今村 広大* 村上 修一* \\ koudai IMAMURA shuichi MURAKAMI
}

\begin{abstract}
Shiga Prefecture Government is planning to redeveloping lakeshore parks as one of the measures of Lake Biwa Comprehensive Preservation and Improvement Project. The objective of this study is to evaluate the accessibility to the parks from the neighborhood' s point of view, in order to gain feedbacks for redesigning them. Spatial continuity between the lakeshore and the adjacent town was analyzed in both plans and sections at the Kitayamada District where the actual conditions of waterfront activities had been investigated previously. Daily uses and needs of the neighbors were also surveyed by the questionnaires. The results showed the problems and their several factors on the accessibility for the neighbors.
\end{abstract}

Keywords: accessibility, neighboring village, use, restotation キーワード：アクセス性, 隣接集落, 利用, 再整備

\section{1. 研究の背景と目的}

琵琶湖湖岸緑地は，1972～97 年の 25 年間にわたる琵琶湖総合 開発事業 ${ }^{1)}$ により建設された湖岸堤の前浜部分に整備された都市 公園である。湖西から湖東にかけて 13 地区 181.1ha の湖岸緑地 は，建設以来，一般に広く利用されてきた。一方，1999 年から 22 力年計画の滋賀県琵琶湖総合保全整備計画 ${ }^{2}$ では, 水質保全, 水源かん養, 自然環境・景観保全について各種施策が総合的に行 われており，その中で「在来生物の生息空間や人の触れあえる空 間としての」33 湖岸緑地の再生整備が目標として掲げられている。 その具体策として 2003 年度より 5 カ年計画で再整備の計画策定 と設計や施工を含む事業 ${ }^{4}$ が進められている。前提として行われ たアンケート調查 ${ }^{5)}$ では, 施設や管理状況に対して具体的な問題 指摘や改善要望が寄せられており, トイレや看板の整備, ゴミ処 理といった施設整備や管理の方向は明らかにされつつあるが，ど のような空間にすべきかに対する意見は利用重視から自然環境重 視まで多様で, 空間整備の方向を見出すことは難しい。むしろ, 広域に点在する湖岸緑地の場合, 空間整備の前提条件が地区の周 辺環境によって異なり, 利用重視, 自然環境重視, あるいは別の 視点といった, 地区ごとに様々な整備の方向が見出されることに なるであろう。したがって, 今後湖岸緑地の再整備にあたって, 利用ニーズへの直接的な対応だけでなく, 利用実態の把握, 地元 地域に扔ける位置づけ, 自然環境との連続性といった複数の視点 からの総合的な検討が必要となる。

湖岸緑地の利用実態については, 既往研究 ${ }^{6}$ で明らかにされ, 親水活動の側面からの空間整備に向けた知見を得ている。また, 自然環境との連続性という視点では, 沿岸域の生態系の連続性が 湖岸堤建設の前後でどのように変化したかについて明らかにされ

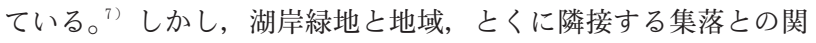
係性についての研究はなされていない。先にあげた県によるアン ケート調查も対象は県民のモニターであって地元を対象にしたも のではない。地元の日常生活の中でどのような位置づけにあるの
か，そして，地元にとってどのような空間が望まれるのかを把握 することは, 今後の再整備に向けた重要な知見となるだろう。日 常生活における位置づけを考察する上で注目されるのは, 湖岸に 行きやすいかどうかというアクセス性である。湖岸堤の建設をと おして, 沿岸集落から湖岸が離れたこと, 間に堤体分のレベル差 が生じたこと, 堤防上に湖周を移動する幹線道路が通ったことか ら, 集落と湖岸が離れ, さらにアクセス動線上に障壁や段差が生 じ歩行困難となり物理的距離が広がったのではないか，また，堤 防により湖水面への視認性の低下，幹線道路の車の通行により道 路横断が困難と考えられることから心理的距離が広がったのでは ないかと推測される。そこで, 琵琶湖全体で 13 地区ある湖岸緑 地のうち, 草津市山田地区の北山田集落に隣接する部分を対象と する。その選定理由としては, (1)湖岸堤建設以前からの沿岸集落 として, 漁業や船便など湖岸との日常的な関わりのあった地区で あること, (2)湖岸堤建設により, 前浜に緑地が整備された一方, 集落との間に広域幹線道路が設置されたこと, が挙げられる。さ らに, (3)前述の既往研究 ${ }^{6)}$ にって湖岸緑地の利用実態が明らか にされた地区であり, 利用頻度が高い一方で, 車によるアクセス の多さ, バーベキュー等の余暇利用への偏重といった特徴から, 近隣住民の日常利用がどの程度あるのかという問題が浮上したこ とも挙げられる。なお, 琵琶湖湖岸と集落との関係を空間断面の 計測により把握した既往研究 ${ }^{8}$ はあるが, 湖岸堤および道路が集 落との間に建設された地区を対象としたものではなく, 湖岸への アクセス性という観点からのものではない。

そこで本研究では, (1)集落・湖岸堤および道路（以下, 湖岸道 路という）・湖岸間の空間を平面および断面で分析し, 集落から 湖岸にいたるアクセス性を左右する要因について考察し, (2)地元 住民の利用実態およびアクセス性に対する考えや要望をアンケー トや聞き取り調査をとおして明らかにした上で, 双方の結果をつ きあわせて, 今後の湖岸整備に向けた有用な知見を得ることを目 的とする。 
また，本研究で得られる知見は，琵琶湖に限らず，海岸，湖岸， 河岸といった水際空間のありかたを考える上でも有用である。目 常的に近隣住民が来訪し，散策，体操，水遊びといった余暇的な 利用や, 見回り, 草刈り, 清掃といった維持管理活動を行うこと で，水際空間は地域に根ざした空間になりうる。こうした近隣住 民の日常的な利用や活動は, 水際空間の質や住民の水際に対する 意識とともに, 水際に対するアクセスのしやすさが前提になると 考えられる。防災や広域交通の観点から水域と隣接地域との間に 設けられる堤防や道路が, アクセス性によ゙のような影響をおよぼ すのか。本研究をと抢して, 水際空間へのアクセス性の検証や改 善のための知見を得られると考える。

\section{2. 研究の方法}

(1)まず，縮尺 2 千 5 百分の 1 の都市計画図および現地調査より， 集落が湖岸堤に隣接する部分から湖岸緑地までの範囲の平面構成 を分析した。調査項目は, 道路, 歩道, 交差点, 階段, 斜路, 陸 橋, 地下道といった動線要素に加えて, 土地利用や施設, 水路, さらに, 信号機, 横断歩道, 標識, 縁石や切り下げ, ガードレー ル, 柵, チェーンといったアクセス性を左右すると予想される要 素の有無や位置関係である。

(2)次に, 平面構成の分析で集落から湖岸へのアクセスに重要と 判断された要素や部分について, レベル測量で比高を計測してレ ベル差や勾配をもとめ断面構成を分析した。

(3)さらに, 集落から湖岸へのアクセス性を左右するもうひとつの 要因と考えられる湖岸道路の交通量を既存調查資料から把握した。

(4)一方, 2005 年 1 月に滋賀県により行われた湖岸緑地再整備 のための地元懇談会において, 山田地区の自治会代表者から, 湖 岸緑地へのアクセスに対する問題意識を聞くことができた。また， 山田地区のまちづくり関係者之の会合においても同様の聞き取り 調查を行った。それらに加えて, 2005 年 8 月に研究対象の湖岸 緑地で開催された地元イベントの来場者に対して, 会場となった 湖岸までの交通手段, 日常の利用頻度と目的, 湖岸緑地に対する 意見や要望についてアンケート調查を行った。

以上の調查で得られた結果をもとに, 湖岸緑地と隣接集落との つながりについてアクセス性という点から考察し, 今後の再整備 に向けての課題と可能性を探った。

\section{3. 結果}

(1) 平面構成の 調査および分析結 果

対象地の平面構 成をみると，湖水 面, ヨシ帯, 湖岸 緑地, 湖岸道路, 漁港, 浄水場, 公 園およびグラウン ド, 水路, 集落ま たは農地，集落内 道路であることが わかる(図 1)。

水域から陸域の 縦断方向の土地利 用構成の違いによ り, (1)堤内にヨシ と水域が隣接し, 堤外に農地が広が る部分, (2)堤内に

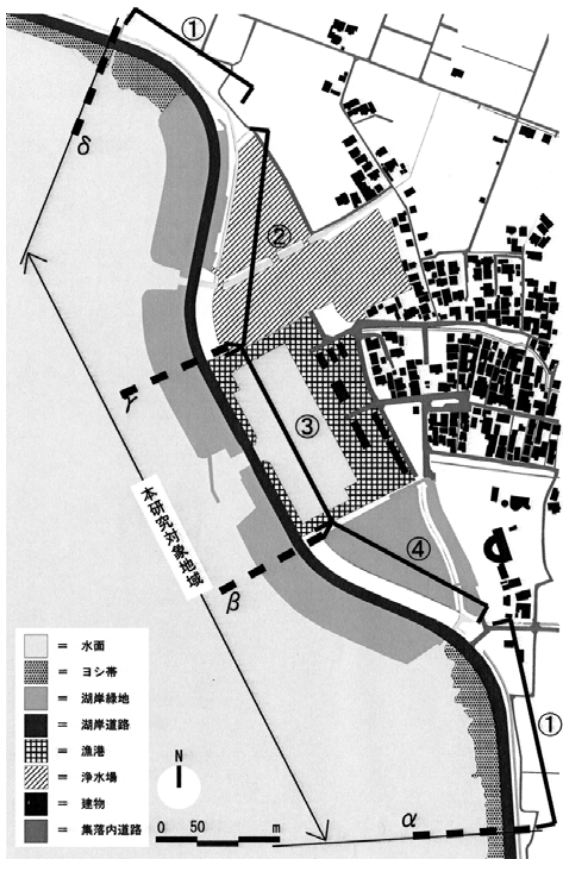

図-1 対象地域の平面構成分析図

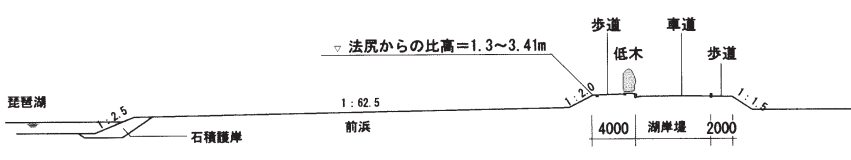

図-2 対象地域の断面構成分析図

湖岸緑地，堤外に浄水場，その奥に集落がある部分，(3)堤内に湖 岸緑地，堤外に漁港，その奥に集落がある部分，(4)堤内に湖岸緑 地，堤外に公園・グラウンド，その奥に集落がある部分の大きく 4 種類に分けることができる。

駐車場, 芝生広場, 東屋, トイレ, 園路, グラウンドなどから なる湖岸緑地は, 合計で約 $42,500 \mathrm{~m}^{2}$ あり, 湖水面に沿って幅 $50 \mathrm{~m}$ ほどの帯状に広がる。集落と琵琶湖の間を横断するように 湖岸道路があり, 片側 1 車線の車道と琵琶湖側に幅約 $4 \mathrm{~m}$, 集落 側に幅約 $2 \mathrm{~m}$ の歩道が敷かれ, 車道と歩道を分ける縁石, ガード レール, 植込みが点在する（図 2)。湖岸道路を越えて集落と湖 岸とを結ぶ動線要素（たとえば，陸橋や地下道など）は無く, ま た, 道路を渡るための横断歩道や信号機も見られなかった。湖岸 堤に隣接して, 北側から浄水場と漁港と公園がある。湖岸堤と集 落の間に位置する浄水場（面積約 $35,000 \mathrm{~m}^{2}$ ) は, 周囲を梱で囲わ れているため立ち入ることはできない。したがって湖岸道路と接 する延長約 $240 \mathrm{~m}$ の(2)の部分で集落から湖岸へのアクセスは不可 能である。一方, 漁港 (面積約 $20,000 \mathrm{~m}^{2}$ ) は, 立ち入りが可能 で, さらに漁港から湖岸道路にでる階段もあり, 湖岸堤に接する 延長約 $260 \mathrm{~m}$ の(3)の部分では集落から湖岸へのアクセスが可能で ある。漁港の南にある公園（面積約 $17,000 \mathrm{~m}^{2}$ ) と湖岸堤との間 には, 幅 $0.5 \mathrm{~m}$ 深さ $0.8 \mathrm{~m}$ の水路があり渡るのは難しい。公園が 湖岸道路と接する延長 $240 \mathrm{~m}$ の (4)の部分で集落から湖岸へのアク セスが可能となっているのは, 一箇所の公園内通路からのみであ る。(1)の部分では, 湖岸堤の堤外法尻に幅 $1.8 \mathrm{~m}$ と $3 \mathrm{~m}$ の 2 種類 の排水路があり集落から湖岸へのアクセスは不可能となっている。

集落（約 500 戸）の構成は, 中心を主動線となる道が通り, そ こから細かな路地が延びている。中心の道路は漁港に通じ漁港手 前で浄水場と公園の方へ分かれている。湖岸道路に接続する集落 内道路はなく, 唯一, 南縁の道路と一箇所で交差するのみである。

次に, 湖岸道路（対象地域内の延長約 $1,260 \mathrm{~m}$ ) に着目すると (図 3), 湖岸堤横断のための要素として, 堤体の法尻と天端を結 ぶ階段および斜路があった。階段は幅 $1 \mathrm{~m}$ で堤外側に 9 箇所, 堤 内側に 12 箇所の計 21 箇所, 斜路は堤外側に 17 箇所, 堤内側に 10 箇所の計 27 箇所であった。加えて, 湖岸道路上の歩道と車道 を区別する高さ $22 \mathrm{~cm}$, 幅 $18 \mathrm{~cm}$ の縁石がその地点において高さ $0 \mathrm{~cm}$ となる切り下げ箇所があった。堤外側に 14 箇所, 堤内側に 11 箇所の計 25 箇所であった。一方, 道路の横断を妨げる要素之 して, 柵, 縁石, ガードレール, 植え込みがあった。堤外側に高 さ $110 \mathrm{~cm}$ の鉄製の柵が延長約 $511 \mathrm{~m}$ あり堤外側の約 $40 \%$, 縁石 が堤外側でほぼ全域に広がり約 85\%, カーブの外側にはガードレー ルがあり, 堤外側で延長 $263 \mathrm{~m}$ （約 21\%）, 堤内側で $196.2 \mathrm{~m}$ （約 15\%）を占めた。また，堤内側には，高さ $40 \mathrm{~cm}$ あるいは $170 \mathrm{~cm}$ の潅木の植込みが所々見られ，植込み延長が 1092.1m（約 87\%） であった。以上のような横断のための要素の位置と, 横断を妨げ る要素のない位置とをみてみると, それらが一致して最短距離で 湖岸道路を横断できる箇所は皆無であった。

\section{(2) 断面構成の調査および分析結果}

図面資料から，集落内から湖岸堤の法尻まではほぼ平坦である ことがわかった。一方, 湖岸堤の法尻からの比高は実測で $1.3 \mathrm{~m}$ から $3.41 \mathrm{~m}$ であった。比高は湖岸道路（図 1) の $\alpha-\beta$ 間および $\gamma-\delta$ 間で， $1.3 \mathrm{~m}$ から $1.6 \mathrm{~m}$ とほぼ平坦である。一方， $\beta-\gamma$ 間で は，その中間あたりに漁港への船の進入路を確保するために高く なり，進入路上で最高 $3.41 \mathrm{~m}$ となる。 
表一 1 アクセス可能要素の 断面分類

\begin{tabular}{|c|c|c|c|c|}
\hline & \multirow{2}{*}{\multicolumn{2}{|c|}{ 図中記号 }} & レベル差 & 勾配 \\
\hline & & & {$[\mathrm{m}]$} & {$[\%]$} \\
\hline \multirow{5}{*}{91} & a & 交差点 & 1.72 & 4.0 \\
\hline & $b$ & 斜路 & 1.12 & 5.6 \\
\hline & c & 斜路 & 0.73 & 1.9 \\
\hline & d & 階段 & 1.24 & 42.9 \\
\hline & e & 階段 & 1.24 & 45.3 \\
\hline \multirow{12}{*}{ 堤内 } & A & 斜路 & 1.59 & 6.1 \\
\hline & $B$ & 斜路 & 1.52 & 6.9 \\
\hline & $\mathrm{C}$ & 階段 & 1.53 & 51.5 \\
\hline & $D$ & 斜路 & 2.71 & 8.0 \\
\hline & $E$ & 斜路 & 3.41 & 11.0 \\
\hline & $\mathrm{F}$ & 階段 & 1.29 & 52.7 \\
\hline & G & 斜路 & 1.60 & 7.6 \\
\hline & $\mathrm{H}$ & 斜路 & 1.68 & 7.6 \\
\hline & I & 斜路 & 1.76 & 8.8 \\
\hline & $J$ & 階段 & 1.55 & 55.3 \\
\hline & $\mathrm{K}$ & 斜路 & 1.47 & 7.7 \\
\hline & L & 階段 & 2.38 & 52. \\
\hline
\end{tabular}

（1）で述べた階段 21 箇所，斜路 27 箇所のうち, 平面構成でアクセス可能と 判断された(3)(4)の部分にあ る堤外の階段 2 䇢所, 斜路 2 箇所, および南縁道路の 交差点, さらに堤内側につ いては湖岸緑地に接続する 階段 4 䇢所, 斜路 8 筒所に ついて詳細な計測を行い, レベル差と平均勾配を算出 した（表 1)。斜路の勾配 はおよそ $8 \%$ 以内であり, 比較的緩やかである。一方, 階段の勾配は $50 \%$ 程度あ り，急であることがわかる。

(3) 湖岸道路の交通量に ついて

草津市北山田町で行われた滋賀県による平成 11 年度の一般交 通量調查 9)の結果を参考にする。平日の 7 時から 19 時の 12 時 間で自動車およびバイク通過車両が 12450 台, 平均時速 $49.2 \mathrm{~km}$ $/ \mathrm{h}$ ，よって，計算上は 3.5 秒に 1 台で通過となる。 8 時から 9 時 のピーク時には 2.5 秒に 1 台となった。休日の 7 時から 19 時の 12 時間で自動車扔よびバイク通過車両が 12341 台, 平均時速 52 . $6 \mathrm{~km} / \mathrm{h}$ ，よって計算上は 3.5 秒に 1 台で通過することとなる。 15 時から 16 時のピーク時には 2.6 秒に 1 台となった。道路の横断 に数秒かかる歩行者を考慮するとこの間隔は非常に狭いと考えら れる。一方, 歩行者の通過は, 平日で 9 人, 休日で43人であった。

\section{（4）地元住民に対する聞き取りおよびアンケート調査の結果}

湖岸緑地再整備の懇談会にお いて，自治会代表者加，地元 の高齢者達にとっては湖岸道路 を横断することが困難で, 湖岸 に近づきにくい，という意見が 出された。また，同様の意見は， まちづくり関係者からも聞き取 ることができた。しかしその一 方で，湖岸堤建設以前の状沉を 知っている高齢者たちからは, 昔は, ヨシ帯で湖岸に近づくこ とができなかったが，現在は，

\section{表 -2 アンケート回答者年齢層}

\begin{tabular}{|r|r|r|}
\hline & 人 & $\%$ \\
\hline \hline$\sim 9$ 歳 & 12 & 18.5 \\
\hline 10 歳代 & 11 & 16.9 \\
\hline 20 歲代 & 12 & 18.5 \\
\hline 30 歳代 & 7 & 10.8 \\
\hline 40 歳代 & 3 & 4.6 \\
\hline 50 歳代 & 5 & 7.7 \\
\hline 60 歳代 & 10 & 15.4 \\
\hline 70 歳代 & 3 & 4.6 \\
\hline 80 歳代 & 1 & 1.5 \\
\hline 記入なし & 1 & 1.5 \\
\hline \hline & 65 & 100 \\
\hline
\end{tabular}
きれいに整備されて湖水面に近づきやすくなった，という意見も 出された。

次に, アンケート調查の結果, 山田地区を含めた草津市在住者 から有効回答数 65 を得た。回答者は男女不問で, 年齢層は表 2 の通りである。そのうち, 当日の交通手段は, 51 人が自動車, バイクが 2 人で, 自転車 9 人, 徒歩 3 人であった。近隣であるに もかかわらず，自転車と徒歩を合わせても $18 \%$ に過ぎない。また， 普段の湖岸緑地の利用頻度は表 3 の通りである。月に 1 回から年 に 2 3 回という回答が多い。湖岸の利用目的は, 釣りが 10 人,

表 -3 湖岸緑地利用頻度

\begin{tabular}{|r|r|r|r|r|r|r|}
\hline & \multicolumn{2}{|c|}{ 山田学区 } & \multicolumn{2}{|c|}{ 草津市内 } & \multicolumn{2}{|c|}{ 合計 } \\
\cline { 2 - 7 } & \multicolumn{1}{|c|}{ 人 } & $\%$ & 人 & $\%$ & 人 & $\%$ \\
\hline 毎日 & 3 & 7.1 & 0 & 0.0 & 3 & 4.6 \\
\hline 週に1回 & 2 & 4.8 & 4 & 17.4 & 6 & 9.2 \\
\hline 月に1回 & 14 & 33.3 & 12 & 52.2 & 26 & 40.0 \\
\hline 年に2〜3回 & 15 & 35.7 & 4 & 17.4 & 19 & 29.2 \\
\hline ほとん゙来ない & 5 & 11.9 & 3 & 13.0 & 8 & 12.3 \\
\hline \hline 記入なし & 3 & 7.1 & 0 & 0.0 & 3 & 4.6 \\
\hline \hline & 42 & 100 & 23 & 100 & 65 & 100 \\
\hline
\end{tabular}

湖に飛来する野鳥の観察 5 人，また眺望や写真撮影も見られた。 その他, 遊び 19 人, 散歩 12 人, 運動 7 人などであった。そのほ か, 湖岸に対する意見として, トイレや水道の清掃について, 放 置ごみについて, 琵琶湖自体の水質や臭いについて等の設備の向 上を求める意見や, ベンチや防犯灯の設置やヨシの植え付けなど, 新たな湖岸緑地の形態を求める意見も見られた。

\section{4. 考察}

（1）平面・断面構成にみるアクセス性の検証

平面構成の結果少ら, 湖岸之隣接集落との間に, 湖岸道路, 浄 水場, 水路, 漁港, 公園があることがわかった。また, 断面構成 の結果から, 集落・琵琶湖間の高さの変化がおこる箇所は湖岸堤 のみであり，その高さは $1.3 \mathrm{~m}$ から $3.41 \mathrm{~m}$ あることがわかった。 湖岸堤を越えるために，階段や斜路を通らなければならない。そ こでルートが限定され，アクセスが困難になっているのではない かと考える。さらに, 湖岸堤の上には高さ $0.4 \mathrm{~m}$ から $1.7 \mathrm{~m}$ の植 え込みやガードレール, 鉄製椢などの横断を妨げる要素もある。 以下, 集落から湖岸へのアクセス性を, 部分ごとに検証していく。 堤内にヨシと水域が隣接し, 堤外に農地が広がる部分(1)では, ほとんど住宅がないためアクセスの頻度が低いと考えられる。さ らに集落からあぜ道を通りアクセスする方法も考えられるが，堤 外側の法尻には水路があり, 湖岸堤上には鉄製柵があるため, 湖 岸道路へのアクセスは困難である。堤内に湖岸緑地, 堤外に浄水 場, その奥に集落がある部分(2)では, 浄水場之湖岸道路は隣接し ており，集落と浄水場は集落内道路でつながっているが，浄水場 の周囲には柵が囲っているため, 集落から湖岸道路へのアクセス は不可能である。堤内に湖岸緑地, 堤外に漁港, その奥に集落が ある部分(3)では, 集落と漁港は集落内の中心道路で直結し, さら に漁港と湖岸道路も階段等のアクセス可能要素でつながっている。 よって, 集落と湖岸道路が結ばれていることから, アクセス可能 ルートを提供できる要素であると考えられる。しかし, 湖岸道路 上のアクセス可能要素(階段, 切り下げなど) と不可能要素（植込 み，縁石など）の位置関係が対応していないため最短距離で湖岸 道路を横断することは難しいと考えられる。堤内に湖岸緑地，堤 外に公園およびグラウンド，その奥に集落がある部分(4)において も, 漁港同様, 集落と公園が集落内道路, 公園と湖岸道路が斜路 によってつながっているため, 集落から湖岸へのアクセス可能ルー 卜を提供できる要素であると考えられるが, (3) と同様に横断要素 の非対応により湖岸道路の横断が困難である。

湖岸道路は集落からの琵琶湖の視認性にも影響をおよぼしてい る。集落がほぼ平坦である一方で, 人の目線 $1.5 \mathrm{~m}$ 前後以上の比 高をもつ湖岸堤は, 湖への眺望を遮る位置にある。さらに, 漁港 へと続く集落内の中心道路は琵琶湖への主要な軸線と考えられる が，その先で湖岸堤は最も高くなっている。

\section{（2）湖岸緑地に対する地元住民の関わりについて}

地元住民への聞き取りから，以下のような意識が浮上した。そ れは，以前はヨシ帯が広がっていた湖岸が，整備により気軽に楽 しめるようになった一方で, 湖岸道路の存在によりアクセスが困 難となり，湖岸に近づきにくくなった，というジレンマである。

アンケート調査の結果より, 湖岸緑地に来た住民の大半が車利 用であったこと, 利用頻度が少ないことから, 湖岸が日常的に気 軽に利用されている空間とはいえないことがわかった。一方，利 用目的としては，遊びや釣りといった余㗇的な利用がほとんどで あり, 既往研究 ${ }^{6}$ で明らかとなった余暇中心の利用と同様であっ た。ただし, 既往研究では多く見られたバーベキュー利用がほと んどなかった一方で, 散歩や運動といった日常的な利用がある程 度はあるという違いが見られ, 湖岸が日常的に利用される可能性 を示唆している。 


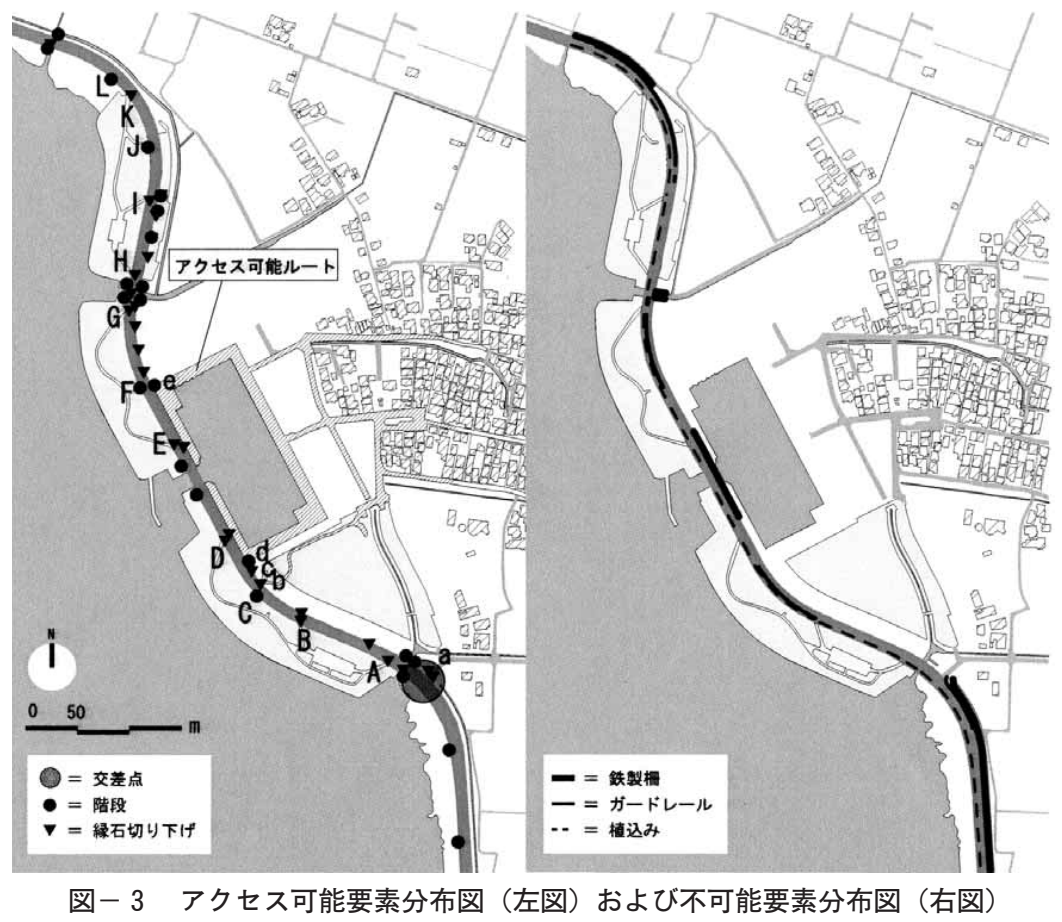

たが，階段については，急であることがわかった。 (4)湖岸道路の交通量調査の結果から，その台数や 車速によって湖岸道路の横断の妨げになっている ことがわかった。

(5)日常的な利用は一部にみられるものの，アクセ ス手段や利用頻度からみて必ずしも地元にとって 日常的とはいえない利用実態が明らかとなった。 (6)湖岸道路のレベル差, 横断を可能にする要素の 少なさ, また可能要素と不可能要素との位置関係 の非対応，さらに湖岸道路の交通量といった要因 が日常利用におけるアクセスを困難にしている。 (7)対策として, 道路横断要素の設置や配置の再検 討, 既存要素の改善, 車速の減速といった空間ハー ドに対するものと湖岸でのイベント開催によるソ フト面のものとが考えられた。

\section{6. 今後の課題}

今回，アクセス性という視点で現状の空間構成 と住民の意見から，湖岸と地元住民の関わりを見 てきたが, 実際の集落内での日常的な活動を把握 するため, 利用実態の外部観察調査が必要である。 また，地域性や精神性などを把握するため, 湖岸 堤建設以前における集落之湖岸の関係を明らかに

\section{（3）空間分析結果と湖岸緑地への地元の関わりの実態の総合考} 察と提言

このように日常的な利用の可能性をもちながらも, アクセス手 段や利用頻度からみて必ずしも地元にとって日常的とはいえない 利用実態の要因としては，以下のようなことが考えられる。すな わち, 湖岸道路, 浄水場, 水路といった湖岸との分断要素の存在, 湖岸道路のレベル差, 横断を可能にする要素の少なさと可能要素 と不可能要素との位置関係の非対応, さらに湖岸道路の交通量が 挙げられることがわかった。したがって, この状況を空間整備の ハード面から改善し地元にとってのアクセス性を向上するために 以下のような対策が必要亡考えられる。それらは，i）信号, 横 断歩道, 地下道といった道路横断要素の設置, ii ) 階段, 斜路等 の横断要素之椢, 植込み等の横断阻害要素の対応配置の再検討, iii）勾配の急な階段を緩やかな斜路に変更するなどの既存要素の 改善, iv）標識などによる車速の減速のための対策, である。と くに, 集落の中心道路と直結する漁港は湖岸道路を越えて湖岸に アクセスするルートを提供する要素であり，この部分にこれらの 対策を行うことでアクセス性の向上が期待できる。さらに, ソフ 卜面での対応として, 湖岸利用を促進させるイベントの開催や, 様々な情報の提供などを行うことによって, より日常的に湖岸を 意識するようになるのではないかと考える。

\section{5. 結論}

本研究の成果をまとめると以下のようになる。

(1)本研究対象地は, 湖水面, ヨシ帯, 湖岸緑地, 湖岸堤扔上び道 路, 漁港, 浄水場, 公園およびグラウンド, 水路, 集落または農 地，集落内道路で構成されている。

(2)集落から湖岸へのアクセスという点では, 集落から漁港や公園 を通り湖岸道路へ出るルートがアクセス可能ルートと考えられる。 (3)湖岸道路を横断する要素として, 交差点, 階段, 縁石切り下げ, 斜路があり, また, 道路の横断を妨げる要素として, 柵, 縁石, ガードレール, 植込みがあった。横断のための要素の位置と, 横 断を妨げる要素のない位置とをみてみると, それらが一致して最 短距離で湖岸道路を横断できる箇所は皆無であった。またその点 における断面構成は, 交差点と斜路については緩やかな勾配であっ
し, 本研究成果との比較を行う必要がある。さらに, 琵琶湖全体 における他の隣接集落の事例の調査も必要であり, これらを総合 的に捉え再整備に向けた知見を得ることも今後の課題である。

なお，本研究は，（財）河川環境管理財団による河川整備基金 助成を受けての研究成果の一部である。

\section{補注及び引用文献}

1）琵琶湖総合開発協議会：『琵琶湖総合開発事業 25 年のあゆ み』，1997 年によれば，琵琶湖総合開発事業では，水資源開 発公団 (現 水資源機構)，国，県，市町村により，水資源開 発と水源地域開発とが一体的に進められた。その中の一つが 洪水を防止する湖岸堤の建設であり, 堤防に沿って道路が, さらにその前浜部分に都市公園が整備された。

2 ) 滋賀県琵琶湖環境部水政課：『マザーレイク 21 計画』〜琵 琶湖総合保全整備計画 , PP.1 14，2000 年。

3 ) マザーレイク 21 計画：滋賀県ホームページ

$<$ http://www.pref.shiga.jp/biwako/koai/mother21/top. $h t m l>, 2000$ 年 3 月公開, 2005 年 10 月参照

4 ) 平成 15 年度組織目標[土木交通部]：滋賀県ホームページ $<$ http://www.pref.shiga.jp/gyokaku/mokuhyo/ doboku/>, 2005 年 10 月参照

5 ) 湖岸緑地に関するアンケート調査結果 : 滋賀県ホームページ, 広報課，（2003 年 8 月，県政モニター 300 人へ郵送による調 查, 230 人 $76.6 \%$ 回答), <http://www.pref.shiga.jp/a/ koho/monitor/ 03080013.html>, 2005 年 10 月参照

6 ) 今村広大・村上修一 (2005)：琵琶湖湖岸緑地における空間 利用についての研究：ランドスケープ研究 68(5), 799-802

7 ) 環境政策研究会 (秋山道雄他) 編 (2002)：琵琶湖沿岸域の 土地利用之景観生態：滋賀県琵琶湖研究所刊

8 ）桧山純子・三村浩史・室崎生子（1988）：水辺環境からみる 集落空間の構成計画その 2 湖岸・小路の断面構成の変容プ ロセス：建築雑誌 104 (1290)，605-608 